\title{
Disfungsionalitas Humanitarianisme: Ekspektasi Kehadiran Resiprositas dalam Isu Vaksinasi Pengungsi dan Pencari Suaka di Indonesia
}

\author{
Alexander Yudho Pratama \\ Debora \\ Samuel Elisa \\ Tristan Noa Araisya \\ Akbar Yudha Susila \\ Universitas Airlangga
}

\begin{abstract}
This paper analyzes the humanitarian act dysfunction in Indonesia, particularly emphasizing the disparity of refugee vaccination as a form of ignorance towards moral obligation. We argue that the presence of reciprocity expectation for Indonesia's effort to vaccinate said group of people caused dysfunctionality. We approach the issue humanitarianly using the concept of global justice to explain the relevance of dysfunctionality and vaccine disparity for refugees as well as the moral obligation within the intermestic dimension. In line with the previously stated notion, the intermestic approach is also used as a catalyst for the re-observation of refugee accommodation strategy within the context of COVID-19 pandemic countermeasures. Indonesia's neglect caused by the country's reluctance becomes more understandable considering the small potential for politicization of these refugee vaccination efforts. Therefore, emphasizing on the rationalism of profit and loss aspect, the reciprocity motive is proven as vital reference through the attention given to the significance of actor's roles and behavior, including state actors.
\end{abstract}

Keywords: humanitarian act; Indonesia; refugees; vaccination; dysfunctionality; COVID-19

\begin{abstract}
Abstrak
Tulisan ini menganalisis perihal disfungsi aksi kemanusiaan di Indonesia dengan secara spesifik menekankan pada ketidakmerataan vaksinasi pengungsi sebagai bentuk pengabaian kewajiban moral. Penulis berargumen bahwa hadirnya harapan resiprositas dalam upaya Indonesia memberikan vaksinasi bagi pengungsi menghasilkan disfungsionalitas aksi humanitarianisme di negara tersebut. Dalam tulisan ini penulis menggunakan pendekatan humanitarian dan konsep global justice untuk menjelaskan relevansi disfungsionalisme aksi humanitarian dan ketidakmerataan vaksinasi, serta obligasi moral dengan dimensi intermestik. Sejalan dengan itu, pendekatan intermestik juga digunakan sebagai katalisator peninjauan ulang strategi akomodasi bagi pengungsi dalam upaya penanganan pandemi COVID-19. Pengabaian Indonesia yang disebabkan oleh keengganan negara tersebut menjadi masuk akal menimbang kecilnya potensi politisasi upaya vaksinasi pengungsi. Oleh karena itu, dengan menekankan pada rasionalisme aspek untung-rugi, motif resiprositas menjadi acuan dengan memperhatikan signifikansi peran dan perilaku suatu aktor, termasuk suatu negara.
\end{abstract}

Kata-kata kunci: aksi kemanusiaan; Indonesia; pengungsi; vaksinasi; disfungsionalitas; COVID-19 


\section{Pendahuluan}

Per bulan September 2021, Indonesia telah berusaha menangani permasalahan pandemi COVID-19 kurang lebih selama satu tahun enam bulan. Kasus COVID-19 di Indonesia mulai terjadi ketika dua masyarakat Indonesia dilaporkan mengalami gejala COVID-19 pada tanggal 2 Maret 2020. Sejak saat itu, kasus COVID-19 mulai tersebar dan menjangkit berbagai golongan masyarakat. Data menunjukkan bahwa pada 31 Maret 2020 terdapat 1.528 masyarakat yang terjangkit virus tersebut dan telah menewaskan 136 korban jiwa (Susilo

et al., 2020). Hingga 13 November 2021, terdapat 4.250 .516 masyarakat yang terjangkit virus tersebut dan telah menewaskan 143.644 korban jiwa (Satuan Tugas Penanganan COVID-19, 2021). Pandemi COVID-19, secara signifikan telah berpengaruh terhadap pemerintahan maupun kehidupan masyarakat Indonesia. Dalam lingkup penyelenggaraan pemerintahan, pandemi ini telah mempengaruhi tingkat ekspor dan impor Indonesia (Dekker, 2020). Hal tersebut disebabkan oleh kebijakan pembatasan wilayah yang bertujuan untuk menekan penyebaran virus melalui barang ekspor-impor dari luar maupun dalam negeri. Selain itu, peningkatan angka pengangguran merupakan salah satu akibat tidak langsung dari pandemi COVID-19 ini. Peningkatan angka pengangguran disebabkan oleh kebijakan pemutusan hubungan kerja (PHK) oleh berbagai perusahaan guna menekan pengeluaran biaya produksi dan mempertahankan perekonomiannya masing-masing.

Perlu dipahami bahwa pandemi Covid-19 juga berpengaruh terhadap kalangan masyarakat marginal seperti kelompok pengungsi dan kelompok pencari suaka di Indonesia. Meskipun Indonesia tidak menandatangani Konvensi Pengungsi Tahun 1951, Indonesia menjadi negara dengan jumlah pengungsi terbanyak ketiga di kawasan Asia Tenggara. Terhitung sejak Desember 2020, terdapat 13.745 pengungsi yang terdaftar di Indonesia (UNHCR, 2020c). Termarginalisasinya kelompok pengungsi dan pencari suaka di Indonesia salah satunya dapat terlihat dari minimnya pemberitaan yang membahas mengenai keadaan pengungsi di Indonesia. Selain itu, meskipun telah bekerja sama dengan United Nations High Commissioner for Refugees (UNHCR) dan International Organization for Migration (IOM), keterbatasan anggaran dana dan kurangnya ketersediaan kebutuhan masih menjadi permasalahan yang dialami oleh kelompok pengungsi di Indonesia pada era pandemi. Joniad (2020) mengungkapkan bahwa penampungan pengungsi di beberapa wilayah seperti Makassar dan Batam menjadi bukti minimnya fokus pemerintah dalam menangani kasus COVID-19 terhadap kalangan pengungsi. Akomodasi yang kurang memadai menyebabkan kelompok pengungsi menjadi lebih rentan terhadap persebaran virus COVID-19. Di Batam, 220 pengungsi dikumpulkan dalam satu rumah dengan ruangan yang terbatas. Satu ruangan berisi delapan orang, tanpa akses yang memadai terhadap kebutuhan sanitasi seperti toilet personal, masker, sabun, ataupun desinfektan. Tanpa KTP, pengungsi hanya bergantung pada tenaga medis dari IOM akibat identitas mereka tidak diterima dalam sistem administrasi rumah sakit (Dana, 2020).

Pada awal 2021, kebijakan penyuntikan vaksin kepada khalayak umum menjadi kebijakan baru yang dilakukan oleh berbagai negara guna mencegah persebaran virus COVID-19. Menurut data Satuan Tugas Penanganan COVID-19 pada tanggal 13 November 2021, terdapat 129,7 juta masyarakat Indonesia yang telah melakukan vaksinasi COVID-19 dosis pertama dan 83,4 juta masyarakat 
Indonesia telah menerima dosis kedua (Satuan Tugas Penanganan COVID-19, 2021). Meskipun begitu, pelaksanaan vaksinasi di Indonesia sejatinya masih belum mampu dilakukan secara signifikan karena dipengaruhi beberapa hal. Konsep nasionalisme vaksin yang dipahami sebagai aksi mengutamakan kebutuhan vaksin domestik dibanding membantu negara lainnya merupakan salah satu faktor tidak langsung yang berperan dalam persebaran vaksin secara merata pada lingkup global, terutama negara berkembang seperti di Indonesia. Lagman (2021) mengungkapkan bahwa konsep ini pada akhirnya hanya akan menguntungkan kelompok kecil negara saja. Pelaksanaan vaksinasi di Indonesia yang lebih berfokus pada masyarakat domestik dibandingkan dengan warga asing juga menjadi kondisi yang memperburuk kondisi kelompok marginal seperti kelompok pengungsi dan pencari suaka. Teuku Faizasyah (2021, dalam BBC, 2021) mengungkapkan bahwa meskipun Kementerian Luar Negeri Indonesia telah bermitra dengan UNHCR, pelaksanaan vaksinasi warga negara asing di Indonesia merupakan tanggung jawab dari Kementerian Koordinator Politik Hukum dan Keamanan. Dengan demikian, rumitnya sistem birokrasi pemerintahan Indonesia juga menjadi faktor penghambat pelaksanaan vaksinasi bagi kelompok pengungsi. Lebih jauh lagi, Tarmizi (BBC, 2021) menjelaskan bahwa Kementerian Kesehatan hingga saat ini lebih memprioritaskan vaksinasi warga negara Indonesia dibanding vaksinasi masyarakat asing.

Kondisi yang telah dijelaskan di atas akan menimbulkan pertanyaan mengenai bagaimana pelaksanaan aksi humanitarian di Indonesia terkait dengan vaksinasi bagi pengungsi dan pencari suaka yang bukan menjadi tanggung jawab pemerintah Indonesia menjadi salah satu isu krusial pada masa pandemi ini. Tulisan ini berasumsi bahwa sejalan dengan isi Pembukaan UUD 1945 yaitu "ikut melaksanakan ketertiban dunia, yang berdasarkan kemerdekaan, perdamaian abadi dan keadilan sosial", pemerintah Indonesia perlu mendukung kesejahteraan kehidupan kelompok masyarakat pengungsi dan pencari suaka. Berpedoman pada teori humanitarianisme penulis akan menjabarkan kewajiban Pemerintah Indonesia dalam memberikan vaksinasi kepada pengungsi dan pencari suaka di Indonesia. Pengambilan dasar teori humanitarianisme sejatinya berkaitan erat dengan cita-cita humanitarianisme untuk meminimalisasi adanya disparitas yang berkaitan dengan isu kesehatan, ekonomi, budaya dan berbagai latar belakang lainnya. Dengan demikian, penulis berargumentasi bahwa pelaksanaan vaksinasi secara penuh adalah sebuah kegiatan yang harus diberikan kepada setiap kalangan masyarakat di Indonesia terlepas dari kewarganegaraannya ataupun latar belakang identitas.

Pengambilan konsep humanitarianisme sebagai dasar kerangka teori tulisan ini sejatinya berkaitan erat dengan konsep human security dalam Studi Politik Keamanan Hubungan Internasional. Pada awalnya, pendekatan keamanan tradisional dalam era Perang Dingin diidentikkan dengan konsep keamanan nasional yang merupakan gabungan dari upaya perlindungan negara, bangsa, maupun kedaulatan negara (Buzan dan Hansen, 2009). Namun seiring dengan perkembangannya, Studi Keamanan telah berkembang dan mulai berfokus pada ancaman non-militer terhadap eksistensi aktor hubungan internasional. Hal ini terbukti dengan kehadiran human security pada era kontemporer. Human Security dapat dipahami sebagai keamanan yang bertujuan untuk melindungi inti utama dari kebebasan manusia dan pemenuhan hak asasi manusia (Report of the Commission on Human Security, 2003 dalam Williams, 2013). Dengan demikian, dapat dipahami bahwa perlindungan hak asasi manusia merupakan hal penting dalam era kontemporer ini. Berkaitan dengan hal tersebut, penulis berargumen 
bahwa konsep humanitarianisme merupakan salah satu bentuk perlindungan dan pemenuhan hak asasi manusia yang kemudian diimplementasikan melalui gerakan vaksinasi bagi kelompok pengungsi dan pencari suaka.

Tulisan ini diharapkan memberikan beberapa kontribusi pada ilmu Hubungan Internasional. Kontribusi pertama dari penelitian ini adalah bahwa nilai altruistis serta nilai dasar humanitarianisme tidak selalu ada pada setiap bantuan humanitarianisme. Argumen ini didasari fakta bahwa pada tahap awal, Indonesia tidak memiliki kepentingan apa pun untuk memberikan bantuan dan meregulasi secara terpusat pengungsi serta pencari suaka di dalam negerinya. Selain itu, hambatan lain seperti tidak terintegrasinya data dari pengungsi dan pencari suaka juga harus dicatat sebagai sebab mengapa hingga kini, pemerintah pusat Indonesia belum bertindak banyak dalam penyelesaian isu. Dari penemuan penulis, justru pemerintah daerah merupakan agen yang menyediakan vaksinasi langsung kepada pengungsi serta pencari suaka tanpa adanya dasar peraturan dari pemerintah pusat. Kurangnya tekanan internasional atas isu humanitarianisme juga menjadi salah satu faktor mengapa pemerintah pusat tidak menempatkan isu ini sebagai prioritas kebijakan negara.

Kontribusi kedua terletak pada kemampuan sintesis humanitarianisme dan keadilan global sebagai pisau analisis, yaitu pemberlakuan konsep keadilan resiprositas terhadap agenda kemanusiaan. Tidak banyak literatur Hubungan Internasional yang membahas gabungan konsep tersebut, tepatnya dengan konsep keadilan resiprokal, sehingga tulisan ini diharapkan dapat berkontribusi untuk menyediakan pengantar bagi bahan bacaan lanjut terkait topik tersebut. Melalui tulisan ini, diharapkan pula bahwa negara-negara dalam kaitannya dengan hubungan internasional, dapat menjadi lebih selektif terkait dengan tawaran bantuan kemanusian ataupun intervensi kemanusiaan yang hendak diberikan oleh negara lain. Hal ini tidak terlepas dari prinsip resiprokal yang senantiasa mengisyaratkan adanya hubungan timbal balik sebagai salah satu bentuk keadilan global. Akan menjadi hal yang tidak wajar apabila dalam aksi humanitarian yang dilakukan oleh negara adalah murni atas dasar kemanusian dengan tanpa mengharapkan adanya resiprokal di dalamnya.

Tulisan ini juga diharapkan mampu menjadi kajian ulang bagi pemerintah dalam kaitannya dengan mewujudkan basis dasar negara yaitu UUD 1945 dan Pancasila, sehingga diharapkan nilai-nilai yang terkandung dalam dasar negara ini tetap mampu dipertahankan kemurnian moralitasnya dan tidak akan berubah seiring dengan perubahan dinamika perpolitikan dari masa ke masa. Besar harapan penulis agar setiap pemegang kekuasaan dan pengambil kebijakan di Indonesia, agar dalam setiap kebijakan yang dirumuskan senantiasa berpacu dan berpedoman pada nilai-nilai bangsa, sehingga akan terdapat konsistensi dalam berperan dan berperilaku baik dalam lingkup domestik ataupun pada lingkup internasional yang lebih luas. Hal ini juga dimaksudkan agar eksistensi dasar negara Indonesia tetap dapat dipertahankan walaupun di tengah adanya arus globalisasi dan perubahan dunia yang semakin masif.

\section{Konsep Humanitarianisme dan Keadilan Resiprokal}

Humanitarianisme merupakan konsep yang mendukung dan mempromosikan kesejahteraan kehidupan manusia sebagai hak penting terlepas dari perbedaan yang ada. Sejarah mengenai kemunculan konsep humanitarianisme hingga saat ini sejatinya masih menjadi perdebatan. Meskipun begitu, sebagian besar pendapat cendekiawan memandang bahwa konsep ini pertama kali muncul 
di kawasan Eropa sebagai akibat dari peperangan dan bencana alam. Ticktin (2015) mengungkapkan cerita yang mengawali kemunculan konsep ini berawal ketika melalui gerakan Henry Dunant dalam menjaga keamanan masyarakat sipil dan penyediaan bantuan kesehatan ketika berperang. Melalui permulaan tersebut, konsep humanitarianisme kemudian semakin berkembang. Barnett (2011, dalam Davey et al., 2013) mengungkapkan bahwa perkembangan humanitarianisme terbagi menjadi beberapa era. Pertama, era imperialisme humanitarianisme yang terjadi pada awal abad ke-19 yang disebabkan oleh Perang Dunia II (PD II). Kedua, neo-humanitarianisme yang terjadi sejak akhir PD II hingga akhir Perang Dingin. Ketiga, humanitarianisme liberal yang dimulai sejak akhir Perang Dingin hingga saat ini.

Pada era kontemporer, gerakan humanitarianisme dapat dilakukan melalui pengiriman bantuan dan intervensi kemanusiaan. Pelaksanaan gerakangerakan tersebut sejatinya berpedoman pada beberapa prinsip utama. Pertama, prinsip kemanusiaan yang menjelaskan bahwa gerakan humanitarianisme harus berpedoman pada perlindungan hidup, keamanan, dan rasa saling menghormati antar-umat manusia (OCHA, 2012). Kedua, prinsip netralitas yang menekankan pada posisi aktor humaniter yang harus bergerak secara netral tanpa dipengaruhi oleh pihak tertentu. Ketiga, prinsip tidak berpihak yang dipahami sebagai prinsip tidak membedakan pihak yang membutuhkan bantuan. Bantuan kemanusiaan harus diberikan secara adil dan merata terlepas dari unsur nasionalisme, agama, ras, maupun unsur lainnya. Keempat, prinsip independen yakni kegiatan humanitarianisme harus bergerak secara mandiri tanpa didorong oleh motif tertentu. Keempat prinsip tersebut pada dasarnya dirumuskan pada Pertemuan Majelis Umum yang dihadiri oleh berbagai negara di dunia. Selain aktor negara, prinsip ini juga telah ditandatangani oleh 492 organisasi internasional (OCHA, 2012).

Konsep humanitarianisme dan keadilan global merupakan isu utama dalam kerangka teori yang lebih besar, yaitu kosmopolitanisme. Pada kosmopolitanisme sendiri, unsur inti terletak pada premis bahwa (1) manusia adalah unit utama dalam isu moral, (2) status manusia sebagai unit utama isu moral berlaku untuk semua orang dan harus diakui oleh semua orang (Pogge, 1992). Perbedaan kontras dari konsep humanitarianisme adalah bahwa humanitarianisme berangkat dari adanya kesadaran tentang adanya kesengsaraan manusia yang tidak disebabkan oleh kesengajaan, sementara keadilan global berputar pada aspek kesejahteraan serta tanggung jawab otoritas. Terdapat beberapa argumen yang menolak bahwa tidak seharusnya aksi humanitarianisme melibatkan kerangka keadilan di dalamnya. Salah satunya adalah bahwa humanitarianisme merupakan aksi amal, bukan keadilan (Simm, 2018). Diamati dari dasarnya, kedua konsep ini memang memiliki akar yang berbeda. Namun kembali lagi pada pernyataan bahwa kedua konsep ini sama-sama disatukan pada kerangka kosmopolitanisme. Selanjutnya, keterkaitan antara dua konsep ini disebabkan karena adanya ketidak cukupan abstraksi teori keadilan dalam memberikan implikasi yang konkret. Dengan adanya hubungan komplementer antara humanitarianisme dan keadilan, maka suatu hasil penelitian dinilai akan lebih membuahkan hasil, bahkan untuk beberapa kejadian dapat menjadi awal formulasi kebijakan. Sehingga, penulis setuju dengan argumen Simm (2018) bahwa sejatinya, humanitarianisme dan keadilan global dapat berjalan beriringan dan sifatnya komplementer. Walaupun kedua konsep dapat digunakan untuk analisis bersamaan, namun penulis juga menyadari bahwa terdapat keterbatasan penggunaannya. Keterbatasan tersebut 
terletak pada ketidakmampuan penggunaan kedua konsep secara bersamaan terhadap semua kasus.

Untuk lebih jauh memahami bagaimana humanitarianisme dan keadilan global dijadikan alat analisis secara bersamaan, maka konsep keadilan global juga perlu dielaborasikan. Konsep keadilan tradisional mulai dari pemikiran bahwa manusia di dunia memiliki posisi setara di dalam hukum alam. Di era modern, konsep keadilan menjadi sedikit melebar dan mulai mencakup ke ranah hak asasi manusia (Qun, 2020). Tidak hanya konseptualisasi dari keadilan saja yang berubah, namun juga pada penyebabnya. Fenomena globalisasi dengan potensi ketimpangan yang besar menyebabkan sumber penderitaan manusia kontemporer (Caney, 2001 dalam McGrew, 2004). Penderitaan tersebut erat kaitannya dengan pemenuhan hak asasi manusia. Semakin lebar kesenjangan yang ada, maka potensi rendahnya pemenuhan hak dasar manusia juga akan tinggi. Konsep keadilan juga erat kaitannya dengan tanggung jawab. Contohnya, ada pada pandangan bahwa institusi pemerintah bertanggung jawab atas keadilan dan kesejahteraan rakyatnya. Di lain contoh, Qun (2020) berpendapat bahwa kemiskinan global merupakan tanggung jawab dari negara maju, baik atas situasi yang sekarang terjadi dan kompensasinya. Setidaknya terdapat empat pandangan besar terkait apa atau siapa yang bertanggung jawab atas ketidaksetaraan global, yaitu dari perspektif konservatif, neokonservatif, naturalis, dan keadilan resiprokal. Teori konservatif memandang bahwa negara merupakan suatu unit yang harus bertanggung jawab. Neo-konservatif di lain sisi memandang bahwa ketidaksetaraan tidak bisa diselesaikan oleh negara karena negara merupakan sumber dari adanya ketidaksetaraan itu sendiri. Ketiga, naturalis berpendapat bahwa adanya ketidaksetaraan merupakan sesuatu yang normal dan tidak bisa diselesaikan. Pandangan terakhir, keadilan resiprokal, memandang bahwa adanya ketidaksetaraan didorong dari tidak adanya hubungan resiprokal antara dua aktor yang saling memberi dalam konteks tertentu.

Konsep keadilan resiprokal merupakan salah satu konsep yang hadir pada teori keadilan global. Konsep resiprokal dapat dipahami sebagai kondisi perilaku suatu pihak yang berpedoman pada perilaku pihak lainnya (Chu, 2018). Konsep resiprokal sejatinya telah hadir sejak tahun 1925 sejalan dengan kemunculan teori resiprokal dan gift exchange yang dicetuskan oleh Marcel Mauss. Konsep ini sejatinya mengungkapkan bahwa setiap aksi yang dilakukan akan selalu memberikan timbal balik. Mauss (1925 dalam Brković, 2020) menjabarkan bahwa terdapat tiga obligasi dalam praktik sosial yaitu pemberian, penerimaan, dan pengembalian hal yang diberikan sebelumnya. Dalam perspektif kelompok resiprokal, pemberian bantuan bukan merupakan hal yang dilakukan secara cuma-cuma. Tidak dapat dipungkiri secara ontologi kondisi pemberi dan penerima bantuan memiliki kondisi yang tidak setara, sehingga akan sulit menciptakan timbal balik terhadap pemberi bantuan. Oleh sebab itu, kelompok resiprokal berargumen bahwa timbal balik dari pemberian tersebut sejatinya dapat dilakukan secara tidak langsung seperti melalui penciptaan hubungan geopolitik dan hubungan sosial dalam lingkup global (Brković, 2020) Dengan demikian, pelaksanaan gerakan humanitarianisme sejatinya menimbulkan perdebatan antara kelompok humanitarian yang mendukung prinsip netralitas-independen dengan kelompok yang mendukung konsep keadilan resiprokal.

Selain perdebatan mengenai netralitas-independen dengan resiprokal, perdebatan humanitarianisme dapat juga terjadi pada perdebatan mengenai hak 
dan kebutuhan. Curtis (2001) menjelaskan bahwa perdebatan ini berpedoman pada tujuan aksi humanitarianisme yaitu sebagai kegiatan amal semata atau sebagai gerakan legal yang wajib bagi setiap negara. Kelompok pendukung humanitarianisme berbasis kebutuhan mengungkapkan bahwa humanitarian yang berpedoman pada hak hanya memberikan kesempatan bagi pendonor untuk terbebas dari konsekuensi ketika humanitarianisme tersebut berdampak negatif. Sedangkan kelompok hak memandang bahwa gerakan humanitarian internasional dan hukum hak asasi manusia merupakan alat penting dalam menahan pemerintah, donor maupun individu yang bergerak pada sebuah aksi humanitarian. Slim (2001 dalam Curtis, 2001) berargumen bahwa aksi humanitarian lebih berfokus pada hak, tugas, dan hukum dibanding berpedoman pada prinsip. Kondisi tersebut pada akhirnya mendorong nilai humanitarian sebagai tugas eksplisit bagi seluruh kalangan masyarakat, serta memberikan kerangka pemikiran yang mampu mengafirmasi nilai universal kemanusiaan.

Lebih jauh lagi, perdebatan juga terjadi pada sistem pemberian bantuan humanitarian. Belloni (2007) berargumen bahwa kebijakan pemberian bantuan humanitarian telah menimbulkan dua bentuk paradoks. Pertama, pemberian dana bantuan acap kali diberikan kepada pihak yang tidak terlalu membutuhkan, dan mengabaikan pihak yang benar-benar membutuhkan. Kedua, mayoritas kawasan miskin dan terbelakang dipandang tidak layak untuk memperoleh dana bantuan humanitarian. Perlu dipahami bahwa dalam praktiknya, pemberian dan pengelolaan dana bantuan secara efisien dan efektif merupakan hal yang cukup sulit. Selain itu, pemberian bantuan humanitarianisme pada dasarnya lebih dapat dilakukan sebagai solusi jangka pendek, dibanding sebagai solusi jangka panjang (Belloni, 2007). Hal tersebut disebabkan oleh fokus humanitarianisme yang lebih berfokus kepada kebutuhan langsung sebuah kelompok, dibanding menyelesaikan akar permasalahan yang ada. Tidak hanya itu, Spiegel (2017) mengungkapkan bahwa sistem humanitarianisme tidak sesuai lagi dengan kondisi era kontemporer dan diperlukan perubahan signifikan.

Melalui penulisan ini, penulis akan berusaha menjabarkan dan menganalisis urgensi pemberian vaksin kepada pengungsi di Indonesia meskipun saat ini Indonesia hanya berperan sebagai negara transit atau tempat sementara bagi kelompok masyarakat pengungsi dan pencari suaka. Data penelitian ini diperoleh melalui hasil pendekatan kualitatif yang kemudian dijabarkan melalui penulisan deskriptif.

\section{Hambatan Pemberian Vaksin bagi Pengungsi dan Pencari Suaka di Indonesia pada Fase Pertama Pandemi}

Setiap negara memiliki kendala yang berbeda-beda dalam menangani isu vaksinasi bagi pengungsi dan pencari suaka. Oleh karena itu, akan dipaparkan dua kondisi terkait dengan kendala pengungsi dan pencari suaka dalam mencari vaksin secara global dan secara nasional di Indonesia. Pada dasarnya UNHCR dan UN Refugee Agency telah mengeluarkan mandat kepada seluruh negara di dunia untuk menghilangkan berbagai pembatasan dan hambatan terkait akses vaksin bagi para pengungsi dan pencari suaka yang tersebar di berbagai belahan dunia. Berdasarkan laporan dari UNHCR, terdapat 91 dari 162 negara yang telah dipantau oleh UNHCR telah mengadakan rencana untuk memberikan jaminan vaksinasi bagi pengungsi dan pencari suaka yang tinggal di sana. Hal ini telah menunjukkan bahwasanya sejatinya telah banyak negara yang mulai peduli terhadap para pengungsi dan pencari suaka (UNHCR, 2021b). 
Meskipun demikian, masih terdapat pula banyak negara yang belum bisa mengambil keputusan untuk dapat memberikan akses vaksin bagi para pengungsi dan pencari suaka. Hal tersebut dikarenakan adanya pertimbangan terhadap kapasitas vaksin setiap negara yang berbeda-beda. Seperti pada negaranegara maju yang memiliki jumlah penduduk rendah sementara pasokan vaksin mereka telah mencukupi seluruh dosis warga negaranya, maka mereka akan dapat memberikan dosis vaksin tersebut kepada para pengungsi dan pencari suaka yang berada di sana. Kondisi tersebut akan jauh berbeda dengan negara-negara berkembang seperti Indonesia, yang memiliki jumlah penduduk yang tinggi akan tetapi, kapasitas dosis vaksin yang mereka punya belum mampu untuk mencakup seluruh atau bahkan sebagian penduduknya (UNHCR, 2021b).

Kondisi awal adanya Covid-19 di Indonesia maupun di dunia pada dasarnya mengacu pada fenomena vaccines nationalism, yaitu ketika negara-negara di seluruh dunia berusaha untuk mengamankan cadangan vaksin bagi masingmasing negaranya. Kesenjangan kepemilikan vaksin tersebut merupakan kendala utama yang mengharuskan pengungsi dan pencari suaka umumnya masih belum mendapatkan akses terhadap vaksin pada gelombang awal. Hal ini karena negara memiliki skala prioritas untuk terlebih dahulu mengutamakan warga negaranya (Santi, 2021). Dengan kondisi gelombang kepemilikan awal dosis vaksin di Indonesia yang demikian, maka pemberian vaksin bagi para pengungsi dan pencari suaka sejatinya bukan berada pada skala utama. Prioritas vaksinasi bagi warga negara lokal diasumsikan mampu untuk menciptakan herd immunity bagi kelompok pengungsi dan pencari suaka. Adanya gagasan ini kemudian juga dianggap pemerintah menjadi alasan logis untuk mengesampingkan dosis vaksin bagi pengungsi dan pencari suaka.

Herd immunity merupakan suatu bentuk perlindungan secara tidak langsung dari sebuah pandemi atau penyakit menular oleh karena mayoritas masyarakat yang ada telah memiliki kekebalan tersebut. Secara lebih singkat, pengungsi dan pencari suaka yang belum mendapatkan akses vaksinasi akan dapat terlindungi secara tidak langsung oleh karena mayoritas masyarakat Indonesia telah memiliki herd immunity (Rahmi et al., 2021). Hal ini merujuk pada kekebalan terhadap potensi terpapar virus Covid-19 yang telah dimiliki oleh mayoritas warga negara Indonesia yang telah tervaksinasi sebagai prioritas utama pemberian vaksinasi. Melalui kondisi kekebalan yang dimiliki oleh mayoritas warga negara, maka pencegahan penularan pandemi Covid-19 untuk kelompok minoritas yaitu pengungsi dan pencari suaka dapat dialokasikan melalui pemberian alat protokol kesehatan terkait dengan masker, hand sanitizer ataupun asupan vitamin dan makanan pokok lainnya yang berguna untuk meningkatkan daya tahan tubuh walaupun kekebalan tubuh melalui vaksin belum terbentuk. Dengan demikian potensi risiko pengungsi dan pencari suaka terpapar virus Covid-19 telah diminimalisasi (Rahmi et al., 2021). 
Respons Pemerintah Daerah dan Keadaan Pengungsi dan Pencari Suaka Dewasa ini Persebaran pengungsi dan pencari suaka yang ada di Indonesia telah teridentifikasi bahwa sebagian besar tersebar di enam wilayah Indonesia yaitu Jakarta, Kupang, Medan, Tangerang, Aceh Timur dan Tanjung Pinang. Meskipun penyebarannya didominasi pada keenam wilayah tersebut, akan tetapi terdapat pula sebagian kecil dari pengungsi dan pencari suaka tersebut juga mendiami daerah-daerah lain di kawasan Indonesia. Hal mendasar yang sejatinya menjadi problem humanitarian untuk pemberian vaksin bagi pengungsi dan pencari suaka di Indonesia adalah terkait dengan fakta bahwa Indonesia bukan merupakan salah satu dari negara-negara yang menandatangani Konvensi PBB tahun 1951 terkait dengan pengungsi. Oleh karena itu, pemerintah Indonesia tidak memiliki hukum utama yang dapat menjamin dan menjaga hak-hak yang seharusnya diberikan dan dimiliki oleh para pengungsi dan pencari suaka yang ada di Indonesia (UNHCR Indonesia, 2021). Hal ini kemudian juga menjadi hambatan terkait pemberian vaksinasi bagi pengungsi dan pencari suaka yang berada di wilayah Indonesia. Kondisi mendasar yang seperti itu juga lantas diperkuat dengan faktor determinan lain yang menjadikan dilema bagi pemerintah Indonesia untuk memberikan akses vaksin bagi para pengungsi.

Faktor determinan lainnya adalah terkait dengan fakta bahwa Indonesia juga hanya menjadi bagian dari negara transit bagi para pengungsi dan pencari suaka. Konvensi 1951 juga menyatakan bahwa Indonesia bukan merupakan negara tujuan dari para pengungsi dan pencari suaka. Akan tetapi, letak strategis Indonesia yang berada di antara Benua Asia dan Australia serta di antara Samudera Pasifik dan Hindia lantas memiliki konsekuensi yang mengharuskan Indonesia menjadi negara transit bagi para pengungsi dan pencari suaka yang kemudian tinggal di Indonesia dalam waktu yang lama (Riadussyah, 2016). Dalam kaitannya dengan hukum resiprositas, dapat dipahami bahwa kekhawatiran besar pemerintah Indonesia sejatinya berkaitan dengan potensi keberlanjutan destinasi pengungsi dan pencari suaka menuju negara tujuan utama. Apabila pemerintah Indonesia telah berusaha secara maksimal untuk memberikan akses vaksin bagi para pengungsi, sementara kemudian mereka pada akhirnya akan berpindah menuju negara tujuan utama, maka dalam hal ini pemerintah Indonesia mengalami kerugian yang cukup besar oleh karena penggunaan anggaran negara yang digunakan untuk menyediakan vaksin bagi para pengungsi kemudian tidak mendapatkan timbal balik yang seimbang.

Namun, faktor penghambatyang telah dijelaskan di atasmerupakankonteks awal gelombang pasokan vaksin yang terbatas. Dewasa ini, keadaan dunia telah menunjukkan signifikansi perubahan yang lebih baik dengan keberadaan pasokan vaksin yang semakin meningkat oleh karena riset dan pengembangan vaksin yang semakin mutakhir. Kondisi yang demikian dapat dilihat pada negara-negara maju yang pada awalnya berfokus pada vaccines nationalism lantas kini mengalami surplus dosis pasokan vaksin, sehingga kemudian mengalokasikannya pada negara-negara lainnya yang jauh lebih membutuhkan pasokan vaksin tersebut. Berdasarkan laporan dari UNHCR Indonesia (2021), Pada 1 September 2021 lalu, Indonesia telah mendapatkan bantuan pasokan vaksin sekitar lebih dari 40 juga dosis vaksin yang dikirimkan melalui mekanisme COVAX dengan dukungan organisasi internasional lain seperti UNICEF dan IOM. Melalui bantuan yang diberikan oleh negara dan organisasi internasional, maka diharapkan Indonesia dapat secara adil mendistribusikan vaksin yang ada kepada masyarakat dan secara khusus kepada pengungsi dan pencari suaka (UNHCR Indonesia, 2021). 
Respons yang diambil oleh salah satu pemerintahan daerah di Indonesia yaitu Jakarta kemudian secara positif berusaha untuk mengakomodasi vaksinasi bagi pengungsi dan pencari suaka. Sebagai salah satu wilayah yang didominasi oleh keberadaan pengungsi dan pencari suaka. Pemerintah Jakarta kemudian mengagendakan vaksinasi massal bagi pengungsi dan pencari suaka di Jakarta yang direalisasikan pada 7 Oktober 2021 lalu dengan cakupan pemberian 600 dosis vaksin pertama. Meskipun demikian, hal ini masih menjadi sebuah tanggung jawab yang besar bagi pemerintah daerah Jakarta karena setidaknya terdapat 4,342 pengungsi dan pencari suaka lain yang masih belum mendapatkan vaksinasi dari total 4,942 pengungsi dan pencari suaka yang ada di Jakarta. Belum menyeluruhnya pemberian vaksin tersebut dapat diidentifikasi melalui hambatan-hambatan lain seperti misalnya ketidakpemilikan atas nomor induk kependudukan sehingga pemerintah tidak dapat mengintegrasikan vaksinasi pada sistem PeduliLindungi yang telah ada. Hambatan ini semakin menjadi lebih kompleks terutama bagi pengungsi dan pencari suaka yang ilegal, sehingga minim atas dokumen dan identitas. Hambatan lain terkait belum maksimalnya pemberian vaksinasi bagi pengungsi dan pencari suaka adalah terkait dengan keterbatasan berbahasa dan informasi yang dimiliki oleh pengungsi dan pencari suaka. Oleh karena itu, terkadang pengungsi dan pencari suaka tidak mengetahui adanya agenda-agenda vaksinasi yang dilakukan pemerintah (Pudjiastuti, 2020).

Namun, sejatinya berbagai hambatan yang terjadi pada dasarnya dapat diatasi ketika pemerintah mau untuk lebih lagi memaksimalisasi kinerjanya. Terkait dengan sistem integrasi ataupun kurangnya informasi yang dimiliki pengungsi sejatinya mencerminkan tidak seriusnya pemerintah dalam mengakomodasi pemberian vaksin bagi pengungsi dan pencari suaka. Penulis kemudian berargumentasi bahwa pelaksanaan yang telah dilakukan pemerintah daerah dan Indonesia pada dasarnya dilakukan sebagai formalitas karena adanya obligasi moral dari pemerintah Indonesia kepada organisasi internasional seperti UNICEF, UNHCR dan IOM. Obligasi moral ini kemudian diperkuat dengan fakta bahwa Indonesia juga telah meratifikasi perjanjian terkait dengan hak asasi manusia, sehingga Indonesia juga memiliki kewajiban internasional untuk memastikan bahwa pengungsi dan pencari suaka mendapat hak-hak dasar mereka seperti misalnya dosis vaksin dalam hal ini (UNHCR Indonesia, 2021). Meskipun Indonesia juga dalam pembukaan UUD 1945 menegaskan adanya keinginan untuk melaksanakan ketertiban dunia dan kemanusiaan yang adil dan beradab, namun kembali lagi bahwa terkadang ketidakhadiran resiprokal dalam hal ini juga akan memengaruhi bagaimana suatu individu atau negara kemudian berperan dan berperilaku.

Pengabaian Isu Vaksinasi Pengungsi dan Pencari Suaka oleh Pemerintah Indonesia Dalam pemaparan sebelumnya telah diketahui bahwa Indonesia bersikap abai terhadap isu vaksinasi pengungsi pada tahap awal penanganan pandemi karena indikasi kurangnya potensi timbal-balik. Timbal balik secara sederhana dapat didefinisikan sebagai saling dependensi, perlakuan setimpal, dan praktik pertukaran 'objek' untuk keuntungan bersama, khususnya hak istimewa yang diberikan oleh satu pemerintah atau lembaga ke yang lain. Dengan merujuk pada pengertian paling terakhir, maka dalam konteks ini, ketiadaan timbal balik memiliki arti adanya ketimpangan usaha atau objek yang diterima oleh salah satu pihak dalam suatu latar sosial yang spesifik. Dengan demikian, hal ini merujuk pula pada konsep keadilan resiprokal, dengan menekankan pada absensi titik 
adil itu sendiri. Hal ini dapat dibuktikan melalui kurangnya akomodasi yang meningkatkan kerentanan terhadap kaum pencari suaka dan pengungsi sebagai salah satu contohnya (Dana, 2020). Fakta ini menunjukkan adanya kekurangan dan kegagalan dalam pemenuhan tiga obligasi utama praktik sosial, yaitu pemberian, penerimaan, dan pengembalian 'jasa' (Mauss, 1925 dalam Brković, 2020).

Bertentangan dengan relativisme budaya stratejik tertentu, dapat dikatakan bahwa standar timbal balik sifatnya universal. Dalam bentuk yang paling dasar, standar timbal balik menetapkan dua tuntutan minimal yang saling berhubungan. Pertama, pihak yang dibantu harus menguntungkan aktor yang telah membantu mereka. Kedua, pihak yang dibantu tidak boleh merusak/merugikan aktor yang telah membantu mereka. Secara umum, norma timbal balik dapat dianggap sebagai dimensi yang ada dalam semua sistem nilai, khususnya sebagai salah satu dari segelintir komponen utama yang secara universal hadir dalam berbagai kode moral, termasuk humanitarianisme yang menjadi fondasi urgensi perlindungan pengungsi dan pencari suaka. Hal ini secara jelas menunjukkan bahwa jika suatu aktor ingin dibantu oleh orang lain, mereka juga melakukan reciprocity. Berdasarkan pada asumsi ala Gouldner, maka motivasi-motivasi 'egoistik' dapat digunakan untuk menjaga stabilitas sistem sosial baik melalui keyakinan eksistensial maupun aturan timbal balik (Gouldner, 1960). Secara tidak langsung, hal tersebut dapat diartikan sebagai justifikasi atas sikap 'abai' Indonesia. Sehingga, sikap abai pemerintah Indonesia tersebut dapat juga diinterpretasikan sebagai keengganan karena ketiadaan timbal balik semata.

Lebih lanjut mengenai ketiadaan resiprokalitas, ketiadaan tekanan sistemik yang nyata menghasilkan pengadaan vaksinasi yang tidak merata. Obligasi moral mendorong Indonesia untuk berlaku adil, namun dengan implementasi yang terhambat oleh absensi fungsi pengawasan menyebabkan pihak pengungsi utamanya hanya terlindungi melalui herd immunity yang dimiliki oleh masyarakat sebagai prioritas penerima vaksin (Rahmi et al., 2011). Perlu ditekankan juga bahwa Indonesia merupakan negara transit, sehingga ada keterbatasan dalam upaya fasilitasi. Sejalan dengan itu, ada kemungkinan besar bahwa para pengungsi ini kemudian ingin atau akan meninggalkan Indonesia untuk pergi ke negara tujuan setelah menerima perlindungan sementara. Umumnya perilaku demikian terjadi karena mereka memang tidak menjadikan Indonesia sebagai negara tujuan utama. Di saat yang sama, tanggung jawab perihal dapat atau tidaknya mereka melanjutkan perjalanan ke negara tujuan tidak hanya terletak pada Indonesia sebagai negara transit, melainkan ada sistem birokrasi berkelanjutan yang melibatkan beberapa pihak seperti UNHCR, IOM, dan negara tujuan bersangkutan (CNN Indonesia, 2021). Dengan berlaku demikian, maka tidak ada pengembalian manfaat bagi Indonesia sebagai fasilitator atas apa yang telah diberikan pada para pengungsi dan pencari suaka ini. Hal tersebut setidaknya cukup untuk menunjukkan tidak adanya resiprokalitas atau timbal balik yang menjadi salah satu alasan utama keengganan Indonesia pada penjelasan sebelumnya. Sejalan dengan itu, lack of interest menjadi masuk akal karena tidak ada yang menarik dari keadaan non resiprokal.

Penulis berargumen bahwa resiprositas merupakan variabel yang selalu dilibatkan pada aksi humanitarianisme. Selanjutnya, penulis hendak memberikan contoh mengenai hubungan antara nilai resiprositas pada aksiaksi humanitarianisme yang dilakukan oleh aktor negara untuk mengontraskan ketiadaan nilai tersebut di Indonesia pada konteks bantuan vaksinasi terhadap pengungsi sehingga menghasilkan suatu disfungsi humanitarianisme. Bantuan humanitarianisme yang ditumpangi oleh kepentingan politik dapat dilihat pada 
era Perang Dingin. Aksi humanitarianisme di saat itu sangat dikaitkan oleh unsur politisasi, bahkan Uni Soviet sempat menolak bantuan dari organisasi nonpemerintah karena dilihat sebagai alat bagi blok Barat untuk memproyeksikan kekuatannya dan melebarkan jurang geopolitik (Whittall, 2015). Bantuan kemanusiaan yang disalurkan pada periodetersebutumumnya dialokasikankarena adanya kepentingan geopolitik, yaitu dengan Uni Soviet dan Amerika Serikat yang membantu aliansinya masing-masing untuk menguatkan loyalitasnya. Sejak saat Perang Dingin, hubungan antara bantuan kemanusiaan dengan kepentingan yang jelas terlihat turut berkontribusi kepada pengembangan konsep etika, obligasi moral, dan keadilan global. Apabila merujuk kepada bantuan dari baik Uni Soviet maupun Amerika Serikat, bantuan mereka jauh dari kata netralitas, ketidakberpihakan, dan independensi. Oleh karena itu melalui studi kasus ini, perdebatan etika di antara cendekiawan dimulai seperti yang disampaikan pada kerangka teori penulisan.

Peninggalan Perang Dingin tentang pemasukan kepentingan terhadap aksi humanitarianisme menyebabkan agensi atau organisasi kemanusiaan sekarang harus melindungi integritasnya. Kini organisasi kemanusiaan pun dilihat sebagai alat penyalur nilai Barat, terutama pada kasus Afghanistan sebelum kudeta pada tahun 2021 untuk menyediakan stabilitas (Whittall, 2015). Willitts-King (2018) kemudian berargumen bahwa keikutsertaan kepentingan nasional dalam aksi humanitarianisme tidak selalu berkonotasi negatif. Ia mencontohkan bantuan Tiongkok terhadap negara-negara Selatan yang didasari atas kepentingan ekonomi dan sebagai sebuah bentuk diplomasi atau solidaritas terhadap sesama negara Selatan. Terdapatnya potensi ekonomi dari diplomasi kemanusiaan ini yang harus digarisbawahi sebagai timbal balik yang didapatkan Tiongkok atas bantuan kemanusiaannya. Sedangkan pada konteks bantuan kemanusiaan oleh Indonesia terhadap pengungsi dan pencari suaka di dalam negerinya, insentif timbal balik tersebut hampir tidak dapat ditemukan. Para humanis yang menginginkan Indonesia supaya membuat regulasi terpusat terkait vaksinasi dan perlindungan pengungsi berekspektasi bahwa Indonesia bisa melakukannya dengan segera karena dorongan kemanusiaan yang berangkat dari nilai altruis. Namun, mereka gagal menyadari bahwa potensi timbal balik yang didapatkan Indonesia hampir tidak ada di samping adanya hambatan lain berupa kendala pada kartu identitas dan sebagainya.

\section{Keterkaitan antara Pendekatan Intermestik dan Humanitarianisme dalam Isu Vaksinasi Pengungsi dan Pencari Suaka di Indonesia}

Kajian mengenai pengabaian Indonesia terhadap vaksinasi para pengungsi dan pencari suaka dapat dijabarkan melalui pendekatan domestikdaninternasional. Adapun selama masa pandemi, terutama pada masa awal penyebaran, pemerintah Indonesia lebih berfokus pada implementasi kebijakan yang sifatnya membangun dengan pendekatan pro-domestik. Hal ini menyebabkan sudut pandang kaum marginal seperti para pengungsi tidak begitu relevan dalam konteks pembuatan kebijakan. Dengan demikian, kepentingan kaum marginal termasuk pengungsi pun terabaikan (Juanda, 2020). Permasalahan juga terjadi sebagai dampak dari disrupsi distribusi pada awal periode pandemi di Indonesia, yang menimbulkan protes dari masyarakat Indonesia. Hal ini menyebabkan pemerintah di masa-masa pertama lebih berfokus pada pemberian vaksin bagi para penduduk yang telah memiliki Kartu Tanda Penduduk Indonesia. Konstruksi terkait upaya revitalisasi vaksin mengalami kendala karena adanya limitasi sistem yang mengendalikan sistem jaminan kesehatan di Indonesia (UNHCR, 2021a). 
Dalam upaya penanggulangannya, Kementerian Luar Negeri RI mengadakan pembicaraan intens dengan pihak-pihak terkait dalam rangka mengakomodir kepentingan pengungsi dalam keterlibatannya atas visi herd immunity Indonesia. Achsanul Habib (2021, dalam Rastika, 2021) sebagai representasi Kemlu RI menjabarkan akomodasi terhadap kaum-kaum rentan melalui penyesuaian identitas pengungsi dan pencari suaka dalam sistem komputerisasi RI. Untuk menyesuaikan permintaan sistem yang membutuhkan 16 digit dalam sistem identifikasinya, kode identitas pengungsi yang hanya terdiri dari lima digit akan diberikan tambahan numerik " 0 " sebanyak 11 digit agar dapat menggunakan layanan kesehatan publik dan aplikasi pandemi seperti PeduliLindungi (Rastika, 2021). Melalui penyesuaian tersebut, Indonesia mampu memulai tahap pertama vaksin bagi pengungsi dan pencari suaka yang berdomisili di Jakarta, Tanjung Pinang, Medan, Tangerang, Kupang, dan Aceh Timur.

Dalam perspektif internasional, terdapat harapan atas pengayaan kondisi sosial dan politik domestik yang dapat memengaruhi manifestasi politik luar negeri suatu negara (Doeser \& Eidenfalk, 2013). Sejalan dengan itu, isu pengungsi dan pencari suaka merupakan isu internasional yang memerlukan kerja sama warga dunia atas dasar tanggung jawab kemanusiaan (United Nations, 2021). Kerja sama di masa mendatang merupakan hal yang diperlukan, mengingat komunitas internasional masih menemui segregasi dan serangan yang diterima pengungsi dan pencari suaka oleh masyarakat di negara transit. Urgensi atas penciptaan jaminan keamanan pengungsi dan pencari suaka merupakan sistem yang beriringan dengan konsep humanitarianisme, dalam perwujudan proteksi yang bersifat resiprokal. Hubungan yang bersifat resiprokal dan perubahan paradigma masyarakat dapat terjadi ketika negara-negara terkait melakukan relaksasi atas pembukaan lapangan kerja yang tidak berbenturan dengan kepentingan-kepentingan strategis Indonesia. Dalam masa pandemi, terdapat pula tanggung jawab Indonesia terlibat sebagai Co-Chair dari COVAX Advance Market Commitment Engagement Group (COVAX-AMC EG). Indonesia terlibat aktif dalam pengawalan terhadap pemberian 100 juta dosis vaksin pada tahun 2021, yang menjadi bagian dari organisasi humaniter dalam penggunaan lima persen dari total vaksin yang disediakan (Kementerian Luar Negeri RI, 2021). COVAX menjadi fokus pemerintah dunia dalam menjamin ketersediaan akses vaksin bagi kaum marginal, terutama yang berpenghasilan rendah dan tidak terlindungi dalam sistem hukum yang berlaku. Mekanisme yang berhasil diwujudkan Pemerintah Indonesia melalui program vaksinasi pengungsi dan pencari di beberapa kota di Indonesia merupakan hal yang diharapkan dapat terjadi di lokasi-lokasi pengungsi di negara lain. Dapat disimpulkan bahwa sinergi antara pendekatan domestik dan internasional menjadi katalisator yang menimbulkan peninjauan ulang atas strategi Indonesia di masa pandemi, terutama terhadap akomodasi kepentingan pengungsi dan pencari suaka.

\section{Kesimpulan}

Berdasarkan argumentasi yang telah disampaikan, penulis berpendapat bahwa motif resiprositas menjadi acuan yang memiliki signifikansi terhadap peran dan perilaku yang akan dilakukan oleh suatu negara. Hal ini tidak terlepas dari asumsi bahwa individu ataupun negara merupakan aktor rasional yang dalam setiap tindakannya akan selalu memerhatikan unsur untung rugi. Meskipun 
dalam konteks humanitarian dan kosmopolitanisme, bantuan kemanusiaan dan intervensi kemanusiaan tanpa adanya motif tertentu masih menjadi gagasan yang bersifat utopis. Terlebih lagi adanya gagasan keadilan global resiprokal yang berasumsi bahwa bentuk keadilan yang sesungguhnya adalah ketika dua pihak yaitu pemberi dan penerima, kemudian saling memiliki hubungan timbal balik sehingga keadaan ketimpangan diargumentasikan lebih minim dalam hubungan resiprokal. Motif resiprokal ini kemudian dapat dilihat dalam kasus utama pada tulisan ini yaitu disfungsionalitas humanitarian pemerintah Indonesia pada pemberian vaksin bagi pengungsi dan pencari suaka yang terjadi oleh karena ketidakhadiran resiprokalitas di dalamnya.

Permasalahan awal terkaitkonsepnasionalisme vaksin dalam perjalanannya mengalami perumusan ulang melalui akomodasi pengungsi dan pencari suaka dalam proses vaksinasi nasional setelah negara mengadakan konsensus dengan organisasi humaniter terkait penerimaan alokasi dari COVAX yang menyediakan jaminan dosis total sebesar lima persen demi menciptakan herd immunity yang inklusif. Sebagai Co-Chair di COVAX AMC, Indonesia memiliki obligasi moral dalam merepresentasikan aktualisasi rencana yang telah dirancang dalam skema GAVI. Di samping itu, permasalahan birokrasi terkait sistem komputerisasi dalam sistem kesehatan domestik telah diselesaikan melalui penyesuaian dan sinkronisasi identitas nasional. Pemerintah RI mengakui identitas lima digit yang diciptakan UNHCR, dan mengimplementasikannya dalam sistem jaminan nasional. Penambahan sebelas digit " 0 " sebagai penyesuaian terhadap kewajiban identitas 16 digit yang bersumber dari NIK merupakan solusi kompromi yang memudahkan akses pengungsi terhadap fasilitas kesehatan terdekat dan programprogram vaksinasi selama pandemi COVID-19.

\section{Daftar pustaka}

Belloni, R. (2007). The Trouble with Humanitarianism. Review of International Studies, 33 (3), pp. 451-474.

Brković, C. (2020). Gift. Dalam A.D. Lauri (Eds.), Humanitarianism: Keywords. Boston: Brill.

Buzan, B., \& Hansen, L. (2009). The Evolution of International Security Studies. Cambridge: Cambridge University Press.

Chu, J.A. (2018). A Clash of Norms? How Reciprocity and International Humanitarian Law Affect American Opinion on the Treatment of POWs. Journal of Conflict Resolution, 63 (5), pp. 1140-1164.

CNN Indonesia. (2021). Ratusan Pengungsi Afghanistan Demo Kemenkumham Jatim [Online], 11 November. Tersedia dalam: <https://www. cnnind onesia.com/nasional/20211111142439-20-719779/ratusanpengungsi-afghanistan-demo-kemenkumham-jatim> [diakses pada 14 November 2021].

Curtis, D. (2001). Politics and Humanitarian Aid: Debates, Dilemmas and Dissension. London: Overseas Development Institute.

Dana, E. (2020). A Call for Help: Refugees Risk Catching Covid-19 in Overcrowded Shelters [Online]. 19 Mei. Tersedia dalam: <https://jakartaglobe.id/opinion/ a-call-for-help-refugees-risk-catching-covid19-in-overcrowded-shelters> [diakses pada 3 September 2021]. 
Davey, E., Borton J., \& Foley M.A. (2013). A History of the Humanitarian System: Western Origins and Foundation. London: Overseas Development Institute.

Dekker, B. (2020). The Impact of COVID-19 Measures on Indonesian Value Chains. The Hague: Clingendael Institute.

Doeser, F., \& Eidenfalk, J. (2013). The Importance of Windows of Opportunity for Foreign Policy Change. International Area Studies Review, 16 (4), pp. 390-406.

Gouldner, A.W. (1960). The Norm of Reciprocity: A Preliminary Statement. American Sociological Review, 25 (2), pp. 161-178.

Hampson, F.O. (2013). Human Security. Dalam P.D. Williams (Ed.), Security Studies: An Introduction. London: Routledge.

Joniad, J.N. (2020). Across Indonesia, latest Covid-19 surge adds to woes of refugees in limbo. [Online]. 31 Mei. Tersedia dalam: https://southeastasiaglobe.com/ refugees-covid-19-indonesia/ [diakses pada 3 September 2021].

Kementerian Luar Negeri Republik Indonesia. (2021). Press Briefing Menlu CoChair COVAX AMC 13 Januari 2021 [Online]. 13 Januari. Tersedia di: $<$ https://kemlu.go.id/portal/id/read/2064/berita/press-briefing-menlu-cochaircovax-amc-13-januari-2021> [diakses pada 10 September 2021].

Lagman, J.D.N. (2021). Vaccine Nationalism: A Predicament in Ending the COVID-19 Pandemic. Journal Public Health, 43 (2), pp. 375-376.

McGrew, A. (2004). Cosmopolitanism and Global Justice. Ritsumeikan Annual Review of International Studies, 3, pp. 1-17.

OCHA. (2012). OCHA on Message: Humanitarian Principles [Online]. Tersedia di: $<$ https://www.unocha.org/sites/dms/Documents/OOM_HumPrinciple_ English.pdf $>$ [diakses pada 3 September 2021].

Pembukaan Undang-Undang Dasar 1945 Negara Kesatuan Republik Indonesia.

Pogge, T. (1992). Cosmopolitanism and Sovereignty. Ethics, 103 (1), pp. 48-75.

Pudjiastuti, T.N. (2020). Kerentanan Pengungsi Pada Masa Pandemi Covid-19 di Indonesia. Jakarta: LIPI.

Qun, G. (2020). Global Justice: A Utopia and Concern of Humanitarianism. Yearbook for Eastern and Western Philosophy, 2019 (4).

Rahmi, A., Salamah, U., \& Nasution, F. U. (2021). The UNHCR Roles for Increasing Refugees Tenacity on the Pandemic Covid-19 Era. Proceeding International Seminar of Islamic Studies, 2 (1).

Rastika, I. (2021). Kemlu Ungkap Kendala Vaksinasi Covid-19 untuk Pengungsi Asing. [Online]. Tersedia dalam: 12 Oktober. Tersedia di: $<$ https://nasional.kompas. $\mathrm{com} / \mathrm{read} / 2021 / 10 / 12 / 20414611 /$ kemlu-ungkap-kendala-vaksinasi-covid19-untuk-pengungsi-asing > [diakses pada 14 November 2021].

Riadussyah, M. (2016). Tanggung Jawab Indonesia sebagai Negara Transit bagi Pengungsi Anak Berdasarkan Hukum Internasional. Jurnal Hukum: Ius Quia Iustum, 23 (2), pp. 230-250.

Santi, S. (2021). Analisis Perlindungan Kesehatan di Masa Pandemi Covid-19 Terhadap Pengungsi Eks Gedung Kodim Kalideres. Jurnal Indonesia Sosial Sains, 2 (4), pp. 605-617.

Satuan Tugas Penanganan COVID-19. (2021). Data Vaksinasi COVID-19 (Update per 13 November 2021) [Online]. 13 November. Tersedia di: <https:// covid19.go.id/berita/data-vaksinasi-covid-19-update-13-november-2021> [diakses pada 14 November 2021].

Simm, K. (2018). Can Theories of Global Justice Be Useful in Humanitarian Response? Cambridge Quarterly of Healthcare Ethics, 27 (2), pp. 261-270.

Spiegel, P.B. (2017). The Humanitarian System is Not Just Broke, but Broken: Recommendations for Future Humanitarian Action. The Lancet. 
Susilo, A., et al. (2020). Coronavirus Disease 2019: Tinjauan Literatur Terkini. Jurnal Penyakit Dalam Indonesia, 7 (1), pp. 45-67.

Ticktin, M. (2015). Humanitarianism's History of the Singular. Grey Room, 61, pp. 81-85.

UNCHR. (2021a). Q\&A: Including refugees in the vaccine rollout is key to ending the pandemic [Online]. 14 Januari. Tersedia di: <https://www.unhcr.org/ news/latest/2021/1/5fff1afe4/qaincluding-refugees-vaccine-rollout-keyending-pandemic.html> [diakses pada 10 September 2021].

UNCHR. (2021b). UNHCR Calls on States to Remove Barriers to Access to Covid-19 Vaccines for Refugees [Online]. 24 Juni. Tersedia di: $<$ https://www.unhcr. org/news/press/2021/6/60d45ebf4/unhcr-calls-states remove-barriersaccess-covid-19-vaccines-refugees.html> [diakses pada 3 September 2021].

UNHCR Indonesia. (2021). Vaccinating Refugees in Indonesia, for the Benefit of All [Online]. 7 November. Tersedia di: <https://news.un.org/en/ story/2021/11/1104922\#> [diakses pada 14 November 2021].

United Nations. (2021). Global Issues Overview [Online]. 10 September. Tersedia di: <https://www.un.org/en/sections/issues-depth/global-issuesoverview/ index.html $>$ [diakses pada 10 September 2021].

Whittall, J. (2015). Is Humanitarian Action Independent from Political Interests? Sur International Journal on Human Rights, 12 (21).

Willits-King, B., et al. (2018). Humanitarian Action and Foreign Policy. London: Overseas Development Institute. 